\title{
Perpustakaan dan Manifestasi Belajar
}

\author{
Supardi \\ Pustakawan IAIN Salatiga
}

\begin{abstract}
Education is basically a conscious effort to develop the potential of human resources by encouraging and facilitating learning activities. Self-learning activities are actually natural human processes in their lives. By learning humans get a lot of benefits, the most important thing is how to realize learning goals in order to maintain survival. In this paper described the importance of learning, the variety of learning and manifestations or manifestations of learning and the role of libraries in the realization of learning.
\end{abstract}

Keywords: learning, learning manifestations, library

\section{Pendahuluan}

Belajar adalah istilah kunci yang paling penting dalam setiap usaha pendidikan. Tanpa belajar sesungguhnya tak pernah ada pendidikan. Sebagai suatu proses, belajar hampir selalu mendapat tempat yang luas dalam berbagai disiplin ilmu yang berkaitan dengan upaya kependidikan.

Perubahan dan kemampuan untuk berubah merupakan batasan yang terkandung dalam belajar. Disebabkan oleh kemampuan berubah,karena belajar, maka manusia berkembang lebih jauh daripada makhluk lainnya, sehingga manusia terbebas dari kemandegan. Boleh jadi karena kemampuan berkembang melalui belajar itu pula manusia secara bebas mengeksplorasi, memilih, dan menetapkan keputusan-keputusan penting untuk kehidupannya. 


\section{a. Arti Penting Belajar}

Sebagian besar perkembangan dalam diri manusia sangat bergantung pada belajar. Menurut fitrahnya setiap bayi yang normal memiliki potensi untuk cakap berbicara seperti ayah bundanya. Namun, kecakapan sang bayi tak akan terwujud dengan baik tanpa upaya belajar walaupun proses kematangan perkembangan organ-organ mulutnya telah sempurna.

Contoh lainnya, seorang anak yang normal pasti memiliki bakat untuk bisa berdiri tegak di atas kedua kakinya. Namun, apabila anak tersebut tidak hidup di lingkungan masyarakat manusia, misalnya dibuang di belantara dan hidup bersama dengan hewan, maka bakat berdiri yang ia miliki secara turun temurun dari orangtuanya tidak akan terwujud. Jika anak tersebut diasuh oleh srigala, tentu ia akan berjalan di atas kedua kaki dan tangannya. Dia akan merangkak seperti srigala. Jadi bakat dan pembawaan dalam hal ini jelas tidak banyak berpengaruh apabila pengelaman belajar tidak turut mengembangkannya.

Belajar juga begitu penting demi mempertahankan kehidupan sekelompok manusia (bangsa) di tengah persaingan yang semakin ketat di antara bangsa-bangsa lainnya yang lebih maju karena belajar. Walaupun akibat persaingan tersebut kenyataan tragis bisa pula terjadi karena belajar. Tidak sedikit orang pintar yang menggunakan kepintarannya membuat orang lain terpuruk atau bahkan menghancurkan kehidupan orang tersebut. Namun demikian, meskipun ada dampak negatif dari hasil belajar kelompok manusia, belajar tetap penting. Karena dengan belajar manusia bisa mempertahankan kehidupannya.

Al hasil, secara ringkas dapat dikatakan bahwa kualitas hasil proses perkembangan manusia itu banyak terpulang pada apa dan bagaimana manusia belajar. Selanjutnya, tinggi dan rendahnya kualitas perkembangan manusia akan menentukan masa depan peradaban manusia.

\section{b. Definisi dan Contoh Belajar}

Belajar adalah kegiatan yang berproses dan merupakan unsur yang sangat fundamental dalam penyelenggaraan setiap jenis dan jenjang 
pendidikan. Artinya berhasil atau gagalnya pencapaian tujuan pendidikan amat bergantung pada proses belajar yang dialami siswa baik ketika berada di sekolah maupun di luar sekolah.

Sebagian mengatakan bahwa belajar adalah semata-mata mengumpulkan atau menghafalkan fakta-fakta yang tersaji dalam bentuk informasi/ materi pelajaran/ materi kuliah. Orang beranggapan demikian biasanya akan segera merasa bangga ketika anak-anaknya telah mampu menyebutkan kembali secara lisan (verbal) sebagian informasi yang terdapat dalam buku teks atau diajarkan oleh gurunya.

Sebagian lainnya, memandang belajar sebagai latihan belaka seperti yang tampak pada latihan membaca dan menulis. Berdasarkan persepsi seperti ini, biasanya mereka akan merasa cukup puas bila anak-anak mereka telah mampu memperlihatkan keterampilan jasmaniah tertentu walaupun tanpa mengetahui mengenai arti, hakikat dan tujuan keterampilan tersebut.

Skinner, seperti dikutip oleh Barlow (1985) dalam Educational Psychology: The Teaching-Leaching Process, berpendapat bahwa belajar adalah suatu proses adaptasi (penyesuaian tingkah laku) yang berlangsung secara progresif.

Hintzman (1978) dalam bukunya The Psychology of Learning and Memory berpendapat bahwa belajar adalah suatu perubahan yang terjadi dalam diri orgnisme, manusia atau hewan, disebabkan oleh pengalaman yang dapat mempengaruhi tingkah laku organisme tersebut. Dalam pandangan Hintzman, perubahan yang ditimbulkan oleh pengalaman tersebut baru dapat dikatakan belajar apabila mempengaruhi organisme.

Reber (1989) dalam kamusnya, Dictionary of Psychology membatasi belajar dengan dua macam definisi. Pertama, belajar adalah proses memperoleh pengetahuan. Pengertian ini biasanya lebih sering dipakai dalam pembahasan psikologi kognitif yang oleh sebagian ahli dipandang kurang representatif karena tidak mengikutsertakan perolehan keterampilan nonkognitif.

Kedua, belajar adalah suatu perubahan kemampuan bereaksi yang relatif langgeng sebagai hasil latihan yang diperkuat. Dalam definisi ini 
terdapat empat aspek penting dalam belajar yaitu, perubahan umum dan menetap, kemampuan bereaksi, penguatan, praktik atau latihan.

Sebagai contoh proses belajar, seorang anak balita dibelikan mainan mobil-mobilan dari ayahnya. Kemudian ia mencoba mainan itu dengan cara memutar kuncinya dan meletakannya di lantai datar. Perilaku "memutar" dan "meletakkan" merupakan respon atau reaksi atas rangsangan yang timbul pada mainan. Pada saat permulaan, respon anak terhadap stimulus yang ada pada mainan tadi biasanya kurang tepat atau kurang teratur. Namun, berkat latihan dan pengalaman berulang-ulang akhirnya ia menguasai dan dapat memainkan mobil-mobilannya dengan baik. Sehubungan dengan contoh ini belajar dapat kita pahami sebagai proses yang dengan proses sebuah tingkah laku ditimbulkan atau diperbaiki melalui serangkaian reaksi atas situasi atau rangsangan yang ada.

\section{Corak Ragam Belajar}

Dalam aspek materi, metode maupun aspek tujuan dan perubahan tingkah laku yang diharapkan setelah proses belajar, terdapat berbagai ragam yang berbeda. Keanekaragaman jenis belajar ini muncul dalam dunia pendidikan sejalan dengan berkembangnya kebutuhan kehidupan manusia yang juga beranekaragam.

\section{a. Ragam Abstrak}

Belajar abstrak merupakan belajar dengan menggunakan cara-cara berpikir abstrak. Tujuannya untuk memperoleh pemahaman dan pemecahan masalah-masalahyang tidak nyata. Dalam mempelajari hal-hal yang abstrak diperlukan peranan akal yang kuat disamping penguasaan atas prinsip, konsep, dan generalisasi.termasuk dalam jenis ini misalnya belajar matematika, kimia, kosmologi, astronomi, dan sebagian materi agama.

\section{b. Ragam Keterampilan}

Belajar keterampilan adalah belajar dengan menggunakan greakangerakan motoric yakni yang berkaitan dengan syaraf dan otot. Tujuannya 
untuk mmeperoleh dan menguasai keterampilan jasmaniah tertentu. Dalam belajar keterampilan amat diperlukan latihan secara intensif dan tertur. Termasuk dalam ragam belajar keterampilan adalah olah raga, memperbaiki alat elektronik, montir, belajar mengemudi.

\section{c. Ragam Penyelesaian Masalah}

Ragam penyelesaian masalah yang dimaksud adalah belajar menggunakan metode-metode ilmiah atau berpikir sistematis, logis, teratur dan teliti. Tujuannya untuk memperoleh kemampuan dan kecakapan kognitif untuk menyelesaikan masalah secara rasional, lugas dan tuntas. Untuk kepentingan ini kemampuan dalam menguasai konsep, prisip dan generalisasi sangat dibutuhkan. Dalam hal ini, hampir semua subyek ilmu pengetahuan dapat dijadikan sebagai obyek belajar penyelesaian masalah.

\section{d. Ragam Rasional}

Maksud belajar rasional adalah belajar dengan menggunakan kemampuan berpikir secara logis dan sistematis. Dengan cara demikian dimaksudkan untuk memperoleh aneka ragam kecakapan menggunakan prinsipprinsip dan konsep-konsep. Ragam rasional berkaitan dengan ragam belajar menyelesaikan masalah. Dengan belajar rasional diharapkan memiliki kemampuan menyelesaikan masalah dengan menggunakan pertimbangan dan strategi akal sehat, logis dan sistematis.

\section{e. Ragam Kebiasaan}

Belajar kebiasaan adalah proses pembentukan kebiasaan baru atau perbaikan kebiasaan yang telah ada. Ragam ini selain menggunakan perintah, teladan dan pengalaman khusus, juga menggunakan hukuman dan hadiah sebagai bentuk apresiasi. Tujuannya untuk memperoleh sikap dan kebiasaan perbuatan baru yang lebih tepat dan positip dalam arti selaras dengan kebutuhan.

'lebih tepat dan positif' juga berarti sesuai dengan norma dan nilai moral yang berlaku baik kultural maupun religi. Belajar kebiasaan juga dapat diberlakukan untuk menopang Pendidikan karakter yang belakangan ini gencar dikampanyekan agar dilaksanakan di sekolah-sekolah. 


\section{f. Ragam Apresiasi}

Belajar apresiasi adalah belajar mempertimbangkan substansi suatu obyek. Tujuannya untuk memperoleh dan mengembangkan kecakapan perasaan dalam hal ini kemampuan menghargai secara tepat terhadap nilai obyek tertentu, misalnya sastra, musik, lukis.

\section{g. Ragam Pengetahuan}

Belajar pengetahuan artinya belajar dengan cara melakukan penyelidikan mendalam terhadap objek pengetahuan tertentu. Studi ini juga dapat dikatakan sebagai program belajar terencana untuk menguasai materi pelajaran dengan melibatkan kegiatan investigasi dan eksperimen (Reber,1988). Tujuan belajar pengetahuan adalah untuk memperoleh atau menambah informasi dan pemehaman trhadap pengetahuan tertentu yang biasanya lebih rumit dan memerlukan cara khusus dalam mempelajarinya, misalnya dengan menggunkan alat-alat laboratorium.

\section{Perpustakaan dan Manifestasi Belajar}

Secara teoretis belajar dapat diartikan sebagai perubahan tingkah laku, namun demikian tidak semua perubahan tingkah laku organisme dapat dianggap belajar. Perubahan yang timbul karena proses belajar sudah tentu memiliki karakteristik perwujudan yang unik.

\section{a. Karakteristik Perubahan Hasil Belajar}

Karakteristik perilaku belajar ini dalam beberapa rujukan disebut juga sebagai Psikologi Pendidikan. Diantara ciri-ciri perubahan khas yang menjadi karakteristik perilaku belajar adalah perubahan intensional, perubahan positif dan aktif, perubahan efektif dan fungsional.

Perubahan intensional adalah perubahan yang terjadi dalam proses belajar berkat pengalaman atau praktik yang dilakukan dengan sengaja dan disadari, dengan kata lain bukanlah kebetulan. Karakteristik ini mengandung konotasi pembelajar menyadari adanya perubahan dalam dirinya, seperti bertambahnya pengetahuan, kebiasaan, sikap dan pendangan tertentu. 
Perubahan positifartinya baik, bermanfaat, serta sesuai dengan harapan. Hal ini juga bermakna bahwa perubahan tersebut senantiasamerupakan penambahan, yakni diperolehnya sesuatu yang baru yang lebih baik daripada apa yang telah ada sebelumnya. Perubahan aktif artinya perubahan tidak terjadi dengan sendirinya seperti karena proses kematangan, tetapi lebih karena usaha aktif pembelajar.

Perubahan efektif yakni berhasil guna, yaitu perbahan tersebut membawa pengaruh, makna dan manfaat tertentu bagi pembelajar. Sedangkan perubahan funsional bermakna perubahan bersifat tetap. Sewaktu-sewaktu dibutuhkan perubahan tersebut dapat direproduksi dan dimanfaatkan. Perubahan efektif - fungsional biasanya juga bersifat dinamis dan mendorong timbulnya perubahan positif lainnya. Misalnya, seorang belajar menulis, maka disamping ia akan mampu merangkai kata dan kalimat dalam bentuk tulisan, ia juga akan mendapatkan kecakapan lainnya seperti membuat catatan, menulis surat, bahkan menyusun karya sastra dan karya ilmiah.

\section{b. Manifestasi Perilaku Belajar}

Timbulnya sikap dan kesanggupan yang konstruktif juga berpikir kritis dan kreatif adalah beberapa sikap sebagai manifestasi perilaku belajar. Disamping itu manifestasi atau perwujudan perilaku belajar biasanya lebih sering tampak dalam perubahan-perubahan sebagai berikut.

\section{Manifestasi Kebiasaan}

Seseorang yang telah mengalami proses belajar, kebiasaannya akan tampak berubah. Menurut Burghardt (1973), kebiasaan itu timbul karena proses penyusutan kecenderungan respon dengan menggunakan simulasi yang berulang-ulang. Dalam proses belajar, pembiasaan juga meliputi pengurangan perilaku yang tidak diperlukan. Karena proses penyusutan/pengurangan inilah, muncul pola bertingkahlaku baru yang relative menetap dan otomatis. Contoh seorang mengulang Bahasa untuk menghindari penggunaan kata yang keliru. Dengan pembiasaan maka diperoleh sikap menggunakan 


\section{Manifestasi Keterampilan}

Ketrampilan adalah kegiatan yang berhubungan dengan urat syaraf dan otot-otot yang lazimnya tampak dalam kegiatan jasmaniah seperti menulis, ,mengetik, olahraga dan sebagainya. Meskipun sifatnya motoric namun keterampilan memerlukan koordinasi gerak yang teliti dan kesadaran yang tinggi. Sehingga seseorang yang belajar dengan kesadaran motoric yang rendah dapat dianggap sebagai kurang atau tidak terampil.

\section{Manifestasi Pengamatan}

Pengamatan artinya proses menerima, menafsirkan dan memberi arti rangsangan yang masuk melalui indera seperti mata, telinga. Berkat pengalaman belajar seseorang akan mampu mencapai pengamatan yang benar obyektif sebelum mencapai pengertian. Pengamatan yang salah akan mengakibatkan timbulnya pengertian yang salah pula. Seorang anak yang baru pertama kali mendengarkan radio akan mengira bahwa penyiar benar-benar dalam kotak bersuara itu. Namun melalui proses belajar, lambat laun akan diketahuinya bahwa yang ada dalam radio tersebut hanya suaranya saja, sedangkan penyiarnya berada jauh di studio.

4. Berpikir Asosiatif dan Daya Ingat

Berpikir asosiatif adalah berpikir dengan cara mengasosiasikan sesuatu dengan lainnya. Berpikir asosiatif merupakan proses pembentukan hubungan antara rangsangan dengan respon. Perlu dicatat bahwa kemampuan seseorang untuk melakukan hubungan asosiatif yang benar amat dipengaruhi oleh tingkat pengetahuan yang diperoleh dari belajar. Daya ingat juga merupakan perwujudan belajar. Ia merupakan unsur pokok dalam berpikir asosiatif. Sehingga seseorang yang telah mengalami proses belajar akan ditandai dnegan bertambahnya simpanan materi (pengetahuan dan pengertian) dalam memorinya, serta meningkatnya kemampuan menghubungkan materi tersebut dengan situasi atau stimulus yang sedang dihadapi.

5. Berpikir Rasional dan Kritis

Berpikir rasional dan kritis adlah perwujudan perilaku belajar terutama 
yang berkaitan dengan penyelesaian masalah. Pada umumnya seseorang yang berpikir rasional akan menggunakan prinsip dan dasar pengertian dalam mejawab pertanyaan "bagaimana" (how), dan "mengapa" (why). Dalam berpikir rasional, seseorang dituntut menggunakan logika (akal sehat) untuk menentukan sebab akibat, menganalisi, menarik kesimpulan, dan bahkan menciptakan hukum-hukum (kaidah teoritis). Dalam hal berpikir kritis, seseorang dituntut menggunakan strategi kognitif tertentu yang tepat untuk menguji keandalan gagasan pemecahan masalah dan mengatasi kesalahan atau kekurangan (Reber, 1988).

6. Manifestasi Sikap

Dalam arti yang sempit sikap berarti pandangan atau kecenderungan mental. Menurut Bruno (1987), sikap (attitude) adalah kecenderungan yang relative menetap untuk bereaksi dnegan cara baik atau buruk terhadap orang atau barang tertentu. Sehingga dapat dianggap sikap adalah suatu kecenderungan untuk bertindak dengan cara tertentu. Dalam hal ini, perwujudan perilaku belajar ditandai dengan munculnya kecenderungan-kecenderungan baru yang telah berubah (lebih maju dan lugas) terhadap suatu objek, tata nilai, peristiwa dan sebagainya.

7. Manifestasi Inhibisi

Inhibisi merupakan upaya pengurangan atau pencegahan timbulnya suatu respon tertentu karena adanya proses respon lain yang sedang berlangsung (Reber, 1988). Dalam hal belajar, inhibisa adalah kesanggupan untuk mengurangi dan menghentikan tindakan yang tidak perlu, lau memilih atau melakukan tindakan tindakan lainnya yang lebih baik ketika ia berinteraksi dengan lingkungannya.

8. Manifestasi Apresiasi

Apresiasi berarti pertimbangan (judgment) mengenai arti penting atau nilai sesuatu (Chaplin, 1982). Dalam aplikasinya, apresiasi sering diartikan sebagai penghargaan atau penilaian terhadap benda-benda baik abstrak maupun konkrit yang memiliki nilai luhur. Apresiasi adalah gejala ranah afektif yang pada umumnya ditunjukkan pada karya-karya 
seni budaya seperti sastra, music, lukis, drama dan sebagainya.

9. Manifestasi tingkah laku Afektif

Tingkah laku afektif adalah tingkah laku yang menyangkut keanekaragaman perasaan, seperti takut, marah, sedih, gembira, kecewa, senang, benci, was-was, dan sebagainya. Tingkah laku seperti ini tidak terlepas dari pengaruh pengalaman belajar. Oleh karenanya ia juga dapat dianggap sebagai perwujudan perilaku belajar.

Seseorang dapat dianggap sukses secara afektif dalam belajar agama apabila ia telah menyenangi dan menyadari dengan ikhlas kebenaran ajaran agama yang ia pelajari, lalu menjadikannya sebagai "system nilai diri”. Kemudian pada gilirannya ia menjadikan system nilai ini sebagai penuntun hidaup, baik di kala suka maupun duka (Darajat, 1982).

Dalam kaitannya dengan fungsi perpustakaan sebagai institusi penyedia informasi, perpustakaan memiliki peran penting dalam menunjang perwujudan atau manifestasi belajar. Pembelajar dapat menemukan informasi melalui layanan dalam perpustakaan. Segala informasi dapat ditemukan dalam perpustakaan sesuai dengan ragam belajar yang diinginkan. Baik ragam abstrak, ragam pengetahuan, ragam apresiasi, ragam kebiasaan, ragam rasional, ragam penyelesaian masalah, maupun ragam ketrampilan. Dalam hal ini perpustakaan memerankan fungsi sebagai institusi rujukan, yang menyediakan referensi baik tercetak maupun non cetak.

\section{Daftar Pustaka}

Barlow, Daniel Lenox. 1985. Educational Psychology: The Teaching Learning Process. Chicago: The Moody Bible Institute.

Bruno, Frank J. 1987. Idictionary of Key word in Psychology. london: Routledge \& Kegan Paul.

Burghardt, Gordon M. 1973. "Instinc and Innate Behavior", dalam Navin, John E. (editor), The Study of Behavior. Illionis Scott, Foresman \& Co. Chaplin, J.P. 1982. Dictinary of Psychology. Fifth Printing. New York: Dell Publishing. Co. Inc. 
Darajad, Zakiah. 1982. Kepribadian Guru. Cetakan ke-tiga. Jakarta: Bulan Bintang

Hintzman, Douglas L. 1978. The Psychology of Learning and Memory. San Fransisco: W.H. Freeman \& Co.

Reber, Arthur S. 1988. The Penguin Dictinary of Psychology. Ringwood Victoria: Penguin Books Australia Ltd.

Syah, muhibbin. 2017. Psikologi Belajar. Depok: Rajawali Pers. 